\title{
Ganges: special at its origin
}

\author{
Krishna Khairnar
}

River Ganges in India, for centuries, has been revered for its "self-cleansing and special healing properties". More than 450 million people depend on the waters of Ganges for many aspects of their life. In 1896, one of the first published works on Ganges water by Ernst Hankin, a British bacteriologist demonstrated antibacterial property of Ganges water against Vibrio cholera [1]. Further work by French microbiologist D'Herelles in the beginning of the twentieth century established that the antibacterial property of Ganges water to be due to a factor, later named "bacteriophage" [2]. The above said studies were conducted during the period of Crown rule in India and a significant number of founding studies on Ganges were carried out mainly by British and French microbiologists. Such studies on Ganges led to the introduction of bacteriophages to the world. Bacteriophages are the prokaryotic viruses that solely infect and/or destroy the bacteria. Bacteriophages were associated with the special property of river Ganges [1,2].

Interestingly, our study for the first time has shown the presence of bacteriophages against putrefying and pathogenic bacteria in the waters of Ganges even at its origin (Fig. 1). The origin of river Ganges is known as Gomukh. Geological studies have proven that the Himalayas had emerged at a site where the Tethys Ocean once existed, as a result of collision between the Indian and Eurasian tectonic plates. Hence, Himalayas' marine origin is known and it has been intriguing to find marine fossils high in the Himalayas [3].

Notably, the physical property of water at the Gomukh is also unique, as observed during the sampling, loads of sediment gushes out in force along with water at this origin site which is due to the melting permafrost. Typically

*Correspondence: k_khairnar@neeri.res.in; kskhairnar@gmail.com Environmental Virology Cell, Council of Scientific and Industrial ResearchNational Environmental Engineering Research Institute, Room-112, Nehru Marg, Nagpur, Maharashtra 440020, India

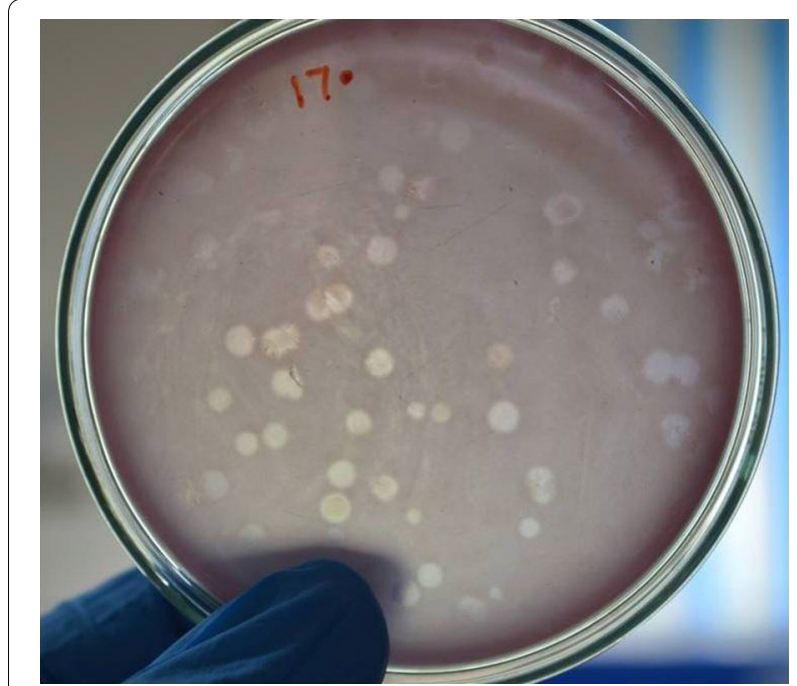

Fig. 1 Representative plate of phages isolated against bacteriaEscherichia spp. at Gomukh's melting permafrost. Plaque assay_clear plaques due to bacteriophage mediated bacterial cell lysis are visible

the Himalayan permafrost [4] melts and forms the origin of Ganges. We believe the bacteriophages trapped at a much earlier time scale in the Himalayan permafrost as abiotic particles are being released gradually with the melting permafrost, thereby making a seed source of bacteriophage at Gomukh. To the best of our knowledge this is the first ground breaking finding of its kind.

A recent publication shows that 30,000 years old frozen giant virus was discovered deep in the Siberian Permafrost, was revived and still infectious [5]. Interestingly, another group has isolated a temperate bacteriophage from Antarctic Dry Valley environment against Psychrobacter-an extremophile and studied its genomic aspects [6]. The above stated findings literally encourage and prompt for further groundbreaking possibilities with exploring bacteriophages and its revival in the frozen Himalayan permafrost. 


\section{Competing interests}

The author declares that he has no competing interests.

Received: 9 May 2016 Accepted: 7 July 2016

Published online: 15 July 2016

\section{References}

1. Hankin EH. L'action bactéricide des eaux de la Jumna et du Gange sur le vibrion du choléra. Ann Inst Pasteur. 1896;10:511-23.

2. d'Herelle F. Sur un microbe invisible antagoniste des bacilles dysentériques. CR Acad Sci Ser D. 1917;165:373-5.
3. Wang Y, Wang X, Xu Y, Zhang C, Li Q, Tseng ZJ, et al. Stable isotopes in fossil mammals, fish and shells from Kunlun Pass Basin, Tibetan Plateau: paleo-climatic and paleo-elevation implications. Earth Planet Sci Lett. 2008;270:73-85.

4. Fort M. Permafrost in the Himalayas: specific characteristics, evolution vs. climate change and impacts on potential natural hazards. Geophysical Res Abst. 2015. http://meetingorganizer.copernicus.org/EGU2015/ EGU2015-4733.pdf.

5. Legendre M, Lartigue A, Bertaux L, Jeudy S, Bartoli J, Lescot M, et al. In-depth study of Mollivirus sibericum, a new 30,000-y-old giant virus infecting Acanthamoeba. Proc Natl Acad Sci USA. 2015;112:E5327-35.

6. Meiring TL, Tuffin IM, Cary C, Cowan DA. Genome sequence of temperate bacteriophage Psymv2 from Antarctic Dry Valley soil isolate Psychrobacter sp. MV2. Extremophiles. 2012;16:715-26.

\section{Submit your next manuscript to BioMed Central and we will help you at every step:}

- We accept pre-submission inquiries

- Our selector tool helps you to find the most relevant journal

- We provide round the clock customer support

- Convenient online submission

- Thorough peer review

- Inclusion in PubMed and all major indexing services

- Maximum visibility for your research

Submit your manuscript at www.biomedcentral com/submit 